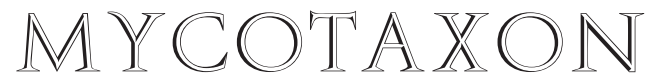

Volume 130, pp. 105-130

http://dx.doi.org/10.5248/130.105

January-March 2015

\title{
Morphology and phylogeny of four new Lactarius species from Himalayan India
}

\author{
Kanad Das ${ }^{1^{*}}$, Annemieke VerbeKen ${ }^{2}$, \& Jorinde NuytincK ${ }^{2,3}$ \\ ${ }^{1}$ Botanical Survey of India, Cryptogamy Unit, Central National Herbarium, \\ Howrah 711103, W.B., India \\ ${ }^{2}$ Ghent University, Department of Biology, Research Group Mycology, \\ K.L. Ledeganckstraat 35, BE 9000, Gent, Belgium \\ ${ }^{3}$ Naturalis Biodiversity Center, Section National Herbarium of the Netherlands, \\ P.O. Box 9517, 2300RA Leiden, The Netherlands \\ *Correspondence to: daskanadbsi@gmail.com
}

\begin{abstract}
Aвstract - Four new species of Lactarius are described from Himalayan India. Lactarius olivaceoglutinus, L. pyriodorus, and L. yumthangensis belong to L. subg. Piperites and $L$. indochrysorrheus is closely related to some representatives of $L$. subg. Russularia. An ITS based phylogeny confirms the phylogenetic placement of the four new species, although the monophyly of neither Lactarius subg. Piperites nor L. subg. Russularia can be confirmed. The ITS data also suggest that the Indian species are closely related to some European and American species.
\end{abstract}

KEY wORDS - ectomycorrhizal fungi, macrofungi, Russulaceae, Sikkim

\section{Introduction}

After segregation of the well-known ectomycorrhizal milkcaps into Lactarius Pers. and Lactifluus (Pers.) Roussel (Buyck et al. 2008, 2010), Lactarius sensu novo comprises three subgenera (Verbeken \& Nuytinck 2013): L. subg. Piperites (Fr. ex J. Kickx f.) Kauffman, L. subg. Russularia (Fr. ex Burl.) Kauffman, and L. subg. Plinthogali (Burl.) Hesler \& A.H. Sm. Lactarius subg. Piperites can be characterized as follows: pileus sticky to slimy/glutinous (more rarely dry and shiny), often hairy and/or zonate or with watery spots; stipe dry or sticky, often scrobiculate (Heilmann-Clausen et al. 1998, Basso 1999). In contrast, representatives of $L$. subg. Russularia typically have dry (rarely somewhat sticky) caps and stipes and colours that are predominantly orange or various tinges of brown (Heilmann-Clausen et al. 1998). 
Sikkim, a small $(0.22 \%$ of the land surface) state in India, lies in Eastern Himalaya, which is part of the Himalaya Hotspot, one of the 34 Global Biodiversity Hotspots (www.biodiversityhotspots.org). Within a very small geographical area it is substantially diverse in flora, fauna, and mycobiota, the latter seriously underexplored. During mycological expeditions to different temperate to subalpine areas of the North District of Sikkim in 2009 (KD \& AV), 2011 (KD), and 2012 (KD), we collected ectomycorrhizal (ECM) fungi, with Lactarius s.l. one of the dominant ECM genera in Dombang, Shingba Rhododendron Sanctuary, and Zema. Dombang is a subalpine coniferous to mixed (coniferous \& broadleaf) forest dominated by Picea spinulosa, Abies densa, Tsuga dumosa, and Larix griffithii. Shingba Rhododendron Sanctuary contains subalpine coniferous and mixed forests distributed in Yumthang valley and its adjoining areas; apart from several Rhododendron species, this protected area is dominated by Abies densa, Picea spinulosa, Tsuga dumosa, Larix griffithii, Magnolia globosa, M. campbellii, Acer pectinatum, and Betula utilis. Zema is a subalpine coniferous forest dominated by Abies densa.

Although Sikkim harbours a large number of russulaceous taxa, only 32 species (out of ca 210 taxa recorded from India) have been reported (Berkeley 1852; Das 2009; Das et al. 2010, 2013; Das \& Verbeken 2011, 2012; Van de Putte et al. 2012). We describe here three new species of Lactarius subg. Piperites (L. olivaceoglutinus, L. pyriodorus, and L. yumthangensis) and one new species of L. subg. Russularia (L. indochrysorrheus).

\section{Materials \& methods}

\section{Morphological study}

Macromorphological characters were described from the fresh basidiomata in daylight. Colour codes and terms follow the Colour identification CHART of British Fungus Flora (Henderson et al. 1969, here prefixed by "a:") or the Methuen HandBook of Colour (Kornerup \& Wanscher 1981, here prefixed by “b:”). Spore print colour codes follow Kränzlin (2005, here prefixed by “c:”).

Micromorphological structures such as basidia, hymenial cystidia, pileipellis, stipitipellis, etc. were observed from free-hand sections of dry samples mounted in a mixture of 5\% KOH, 30\% Glycerol, Phloxine, and Cotton Blue using an Olympus CX41 compound microscope. Spores and spore ornamentation were studied in Melzer's reagent. Drawings were made from SEM images obtained in different magnifications. Spore measurements were calculated based on 20 basidiospores per specimen; dimensions represent minimum-mean-maximum length $\times$ minimum-meanmaximum width, and $\mathrm{Q}=$ length/width ratio. Herbarium names are after Holmgren et al. (1990).

\section{DNA extraction, PCR amplification and sequencing}

DNA was extracted from dried fruiting bodies according to Nuytinck \& Verbeken (2003) with slight modifications (Van de Putte et al. 2010). The internal transcribed 
TABLE 1. Collections of Lactarius and allied species used for molecular analyses.

\begin{tabular}{|c|c|c|c|c|}
\hline SPECIES & VOUCHER & Herbarium & ORIGIN & Genbank \\
\hline Lactarius akahatsu & Verbeken 04-141 & GENT & Thailand & KF133269 \\
\hline \multirow[t]{2}{*}{ L. albocarneus } & Verbeken 98-071 & GENT & France & KJ742389 \\
\hline & Verbeken 98-080 & GENT & France & KF241545 \\
\hline L. alboscrobiculatus & Le 175 & CMU, SFSU, GENT & Thailand & EF141538 \\
\hline L. aspideus & Walleyn 3815 & GENT & Czech Rep. & KJ742390 \\
\hline L. atroviridis & Verbeken 05-306 & GENT & USA & KF133270 \\
\hline L. auriolla & Walleyn 1601 & GENT & Sweden & KF133257 \\
\hline L. indochrysorrheus & KD 11-002 (Holotypus) & BSHC, GENT & India & KJ742391 \\
\hline L. azonites & Verbeken 00-124 & GENT & Belgium & KF241540 \\
\hline \multirow[t]{4}{*}{ L. brunneoviolaceus } & Verbeken 04-220 & GENT & France & KJ742392 \\
\hline & Verbeken 04-249 & GENT & France & KJ742393 \\
\hline & Walleyn 1605 & GENT & Sweden & KJ742394 \\
\hline & Eberhardt 24.08. 04-8 & UPS & Sweden & KJ742395 \\
\hline L. caespitosus & & & & FJ845421 \\
\hline L. camphoratus & Oberwinkler 46773 & TUB & Germany & AY606945 \\
\hline L. chichuensis & Wang 1236 & HKAS & China & KF475766 \\
\hline \multirow[t]{3}{*}{ L. chrysorrheus } & Nuytinck 01-089 & GENT & Belgium & KJ742396 \\
\hline & D’Hooge 08-020 & GENT & France & KJ742397 \\
\hline & Eberhardt 04.10. 02-8 & UPS & Italy & KF133261 \\
\hline \multirow[t]{2}{*}{ L. aff. chrysorrheus } & Verbeken $04-212$ & GENT & USA & KJ742398 \\
\hline & Verbeken 05-359 & GENT & USA & KJ742399 \\
\hline L. citriolens & Eberhardt 20.09.04-3 & UPS & Sweden & DQ422003 \\
\hline L. controversus & Verbeken $00-117$ & GENT & Italy & KF241544 \\
\hline L. crassiusculus & Le 369 & CMU, SFSU & Thailand & EF560684 \\
\hline L. cyathuliformis & Eberhardt 04.09.04-3 & UPS & Sweden & KF133266 \\
\hline \multirow[t]{3}{*}{ L. flexuosus } & Walleyn 2136 & GENT & Sweden & KJ742400 \\
\hline & Walleyn 3178 & GENT & Czech Rep. & KJ742401 \\
\hline & Eberhardt 06.09.02-1 & UPS & Sweden & DQ421992 \\
\hline L. formosus & Le 382 (Holotypus) & CMU, SFSU, GENT & Thailand & EF141549 \\
\hline L. fuliginosus & Basso 97-24 & priv. herb. & Sweden & JQ446111 \\
\hline L. helvus & Eberhardt 08.09. 04-1 & UPS & Sweden & KF133263 \\
\hline L. lilacinus & Walleyn 3774 & GENT & Belgium & KF133275 \\
\hline \multirow[t]{7}{*}{ L. luridus } & Taylor 2003066 & UPS & Sweden & KJ742402 \\
\hline & Eberhardt 17.09.04-3 & UPS & Sweden & KJ742403 \\
\hline & Eberhardt 10.10. 04-4 & UPS & Sweden & KJ742404 \\
\hline & Berteloot 11-011 & GENT & Belgium & KF241547 \\
\hline & Berteloot 11-012 & GENT & Belgium & KJ742405 \\
\hline & Taylor 2004254 & UPS & Sweden & KJ742406 \\
\hline & Walleyn 1455 & GENT & Belgium & KJ742407 \\
\hline L. montoyae & KD 1065 (Holotypus) & BSD & India & EF560673 \\
\hline L. necator & Verbeken 04-231 & GENT & France & KF133276 \\
\hline L. olivaceoglutinus & KD 11-103 (Holotypus) & BSHC, GENT & India & KJ742408 \\
\hline L. pallescens & & & & DQ974747 \\
\hline L. peckii & Nuytinck 04-020 & GENT & USA & KF133277 \\
\hline \multirow[t]{2}{*}{ L.pseudouvidus } & Eberhardt 24.08. 04-14 & UPS & Sweden & KJ742409 \\
\hline & Eberhardt 24.08. 04-13 & UPS & Sweden & KJ742410 \\
\hline
\end{tabular}


108 ... Das, Verbeken, \& Nuytinck

\begin{tabular}{|c|c|c|c|c|}
\hline L. pubescens & Eberhardt 15.09.02-2 & UPS & Sweden & DQ421996 \\
\hline L. pyriodorus & KD 11-027 (Holotypus) & BSHC, GENT & India & KJ742411 \\
\hline L. quieticolor & Eberhardt 10.09.04-1 & UPS & Sweden & DQ422002 \\
\hline L. quietus & Eberhardt 16.09.04-6 & UPS & Sweden & KF133264 \\
\hline L. rufus & Nuytinck 02-008 & GENT & Norway & KF241543 \\
\hline L. sphagneti & Walter 083 & TUB & Germany & KJ742412 \\
\hline L. subdulcis & Vervisch 06-024 & GENT & Belgium & KF133279 \\
\hline L. subplinthogalus & Verbeken 04-219 & GENT & USA & KF241539 \\
\hline L. subsericatus & Eberhardt 11.10.04-8 & UPS & Sweden & DQ422011 \\
\hline L. thyinos & Voitk 23-08-04 & priv. herb. & Canada & KF133271 \\
\hline L. torminosus & Walleyn 3183 & GENT & Czech Rep. & KF133281 \\
\hline \multirow[t]{3}{*}{ L. trivialis } & Van de Putte 10-011 & GENT & Russia & KJ742413 \\
\hline & Walleyn 3179 & GENT & Czech Rep. & KJ742414 \\
\hline & Eberhardt27.08. 02-17a & UPS & Sweden & DQ421991 \\
\hline \multirow[t]{5}{*}{ L. uvidus } & Van de Putte 10-027 & GENT & Russia & KF241546 \\
\hline & Nuytinck 01-033 & GENT & Finland & KJ742415 \\
\hline & Walleyn 1237 & GENT & France & KJ742388 \\
\hline & Walleyn 2119 & GENT & Sweden & KJ742416 \\
\hline & Eberhardt 28.08. 02-24 & UPS & Sweden & KJ742417 \\
\hline L. vietus & Eberhardt 11.10.04-1 & UPS & Sweden & KF133267 \\
\hline L. vinaceorufescens & Nuytinck 07-018 & GENT & Canada & KF241542 \\
\hline L. yumthangensis & KD 11-147 (Holotypus) & BSHC, GENT & India & KJ742418 \\
\hline Lactifluus volemus & Eberhardt 09.08. 04-5 & UPS & Sweden & DQ422008 \\
\hline \multirow{3}{*}{$\begin{array}{l}\text { Lactifluus vellereus } \\
\text { Multifurca } \\
\text { ochricompacta } \\
\text { M. zonaria }\end{array}$} & Eberhardt 20.09.04-22 & UPS & Sweden & DQ422034 \\
\hline & Buyck 02-107 & $\mathrm{PC}$ & USA & DQ421984 \\
\hline & Desjardin 7442 & SFSU, PC, BBH & Thailand & DQ421990 \\
\hline Russula cyanoxantha & Eberhardt 29.09. 02-2 & UPS & France & DQ422033 \\
\hline R. nigricans & Eberhardt 20.09.04-7 & UPS & Sweden & DQ422010 \\
\hline
\end{tabular}

spacer region of the nuclear ribosomal DNA (ITS) was amplified and sequenced using primers ITS1-F and ITS4 (White et al. 1990, Gardes \& Bruns 1993). PCR amplification protocols follow Le et al. (2007); sequencing was conducted with an ABI 3730XL or ABI 3700 by MACrogen (Amsterdam, The Netherlands). Sequences were assembled and edited with Sequencher ${ }^{\mathrm{TM}}$ v4.9 (GeneCodes Corporation, Ann Arbor, Michigan, U.S.A.). Specimens and sequences used in the phylogenetic analysis are shown in TABLE 1.

\section{Alignment and phylogenetic analyses}

Alignment was conducted with the on-line version of MAFFTv7 (Katoh \& Standley 2013), applying the E-INS-I strategy, a very slow method recommended for fewer than 200 sequences with multiple conserved domains and long gaps. The alignment was manually refined in BioEdit v7.0.9.0 (Hall 1999). Ambiguously aligned positions were detected using Gblocks v0.91b (Castresana 2000), specifying less stringent conditions than default. The minimum number of sequences for a conserved position and for a flank position was set to half the number of sequences, the number of contiguous nonconserved positions was set to 10 , and the minimum length of a block after gap cleaning to 5 and positions with gaps were not treated differently from other positions. The ITS 


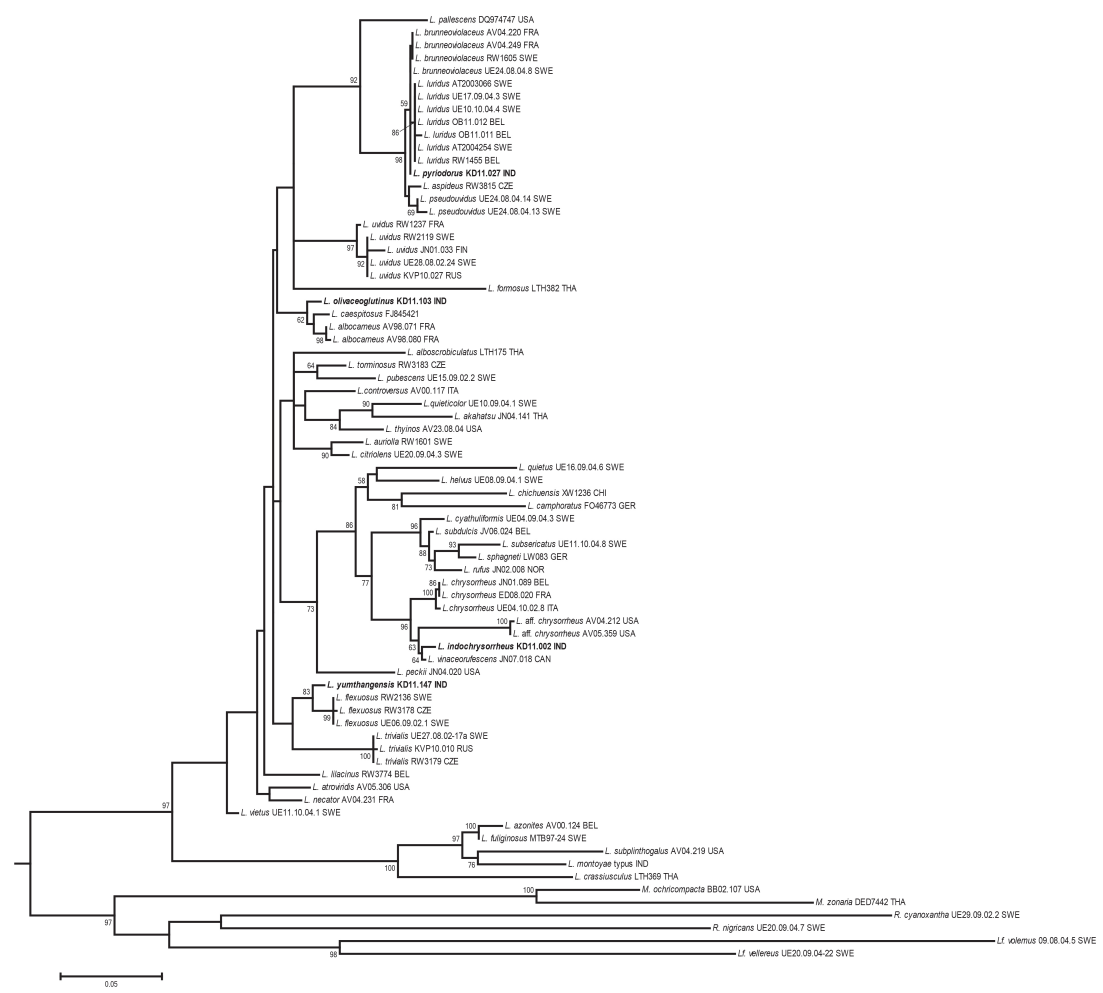

Plate 1. The obtained ML topology based on ITS sequences of Lactarius, Multifurca, Russula, and Lactifluus species. Bootstrap values $>50 \%$ are indicated. Names in bold are the new Indian species described in this paper. The scale bar represents the number of nucleotide changes per site.

sequences were partitioned into 5 partitions: the ribosomal genes $18 \mathrm{~S}, 5.8 \mathrm{~S}$, and LSU and the spacer regions ITS1 and ITS2.

Maximum Likelihood (ML) analysis was performed in RAxML v7.0.3 (Stamatakis 2006), combining a ML search with the Rapid Bootstrapping algorithm for 1000 replicates. The model GTRGAMMA was estimated for each partition separately.

\section{Results}

\section{Phylogeny}

PLATE 1 shows the obtained ML topology with bootstrap support (BS) values $>50 \%$ displayed. The tree shows a well-supported genus Lactarius (97\% BS). Within Lactarius, L. subg. Plinthogali receives a high support value (100\% BS), but monophyly of neither Lactarius subg. Piperites nor L. subg. Russularia (sensu Heilmann-Clausen et al. 1998) is supported. Lactarius pyriodorus, L. olivaceoglutinus, and L. yumthangensis are closely related to species 
traditionally placed in L. subg. Piperites. Lactarius indochrysorrheus is closely related to the European L. chrysorrheus Fr. and the North American L. vinaceorufescens A.H. Sm. and $L$. aff. chrysorrheus, which are assigned to $L$. subg. Russularia in morphology-based taxonomy.

Species delimitation for this paper is mainly based on morphological features. We were not able to include enough specimens/sequences from the newly proposed species to test species delimitation in the phylogenetic tree.

\section{Taxonomy}

Lactarius indochrysorrheus K. Das \& Verbeken, sp. nov.

Plates 2, 3, 6A,B,E MycoBank MB804887

Differs from Lactarius chrysorrheus by its more viscid pileus with its pileipellis an ixocutis covered by a thick gelatinous layer.

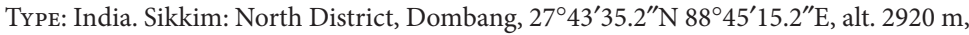
18.VIII.2011, K. Das, KD 11-002 (Holotype, BSHC; isotype, GENT).

ЕтумоLоGy: an Indian look-alike of the European Lactarius chrysorrheus.

PiLeus 25-70 mm diam., convex with slightly pubescent and inrolled margin when young, gradually planoconvex to applanate with slightly depressed centre, rarely with a central papilla, sometimes becoming widely infundibuliform; margin decurved with maturity, becoming very irregularly wavy; surface smooth to greasy, viscid (sticky), shiny, brownish orange, pinkish buff to salmon (a: 45) or orange (b: 6A6) (cinnamon (a: 10) to somewhat rusty after maturity), gradually apricot cream to paler up to yellow (a: $5 \mathrm{E}$ ), towards margin distinctly zonate with several zones over the whole diameter but most dense in the center; zones consisting of darker and watery spots; margin very faintly and shortly striate. LAMELLAE subdecurrent, crowded $(18-22 / \mathrm{cm}$ at pileus margin), pale yellow (a: 4D) when young, gradually pink-spotted, finally becoming brown to reddish brown, with lamellulae in 9 series; edge entire, concolorous. STIPE $45-65 \times 6-8.5 \mathrm{~mm}$, slender, subcylindrical to cylindrical or slightly widened towards base; surface smooth, slightly greasy, strigose (hairy) at base, much paler than the pileus, especially in the upper part (very pale pinkish), very pale salmon to vinaceous, gradually darker up to rust to rusty tawny or pale brick red. Context hollow in stipe, pinkish yellow (a: $4 \mathrm{D}$ ) to pale salmon, turning lemon yellow (a: 54) to greenish yellow (a: 57) after cut, changing to salmon (a: 45) with $\mathrm{FeSO}_{4}$, and greenish with Guaiac. LateX abundant, white, turning quickly to greenish yellow. TASTE first mild, then becoming bitter and acrid. ODOUR not distinctive. SPORE PRINT pale cream (c: $10 \mathrm{Y}$ ).

BASIDIOSPORES 6.4-7.4-8.5 × 5.6-6.2-6.9 $\mu \mathrm{m},(\mathrm{Q}=1.08-1.18-1.33)$, subglobose to ellipsoid; ornamentation amyloid, $\leq 0.9 \mu \mathrm{m}$ high, composed of conical to spine-shaped warts, with short or medium, irregular to regular 


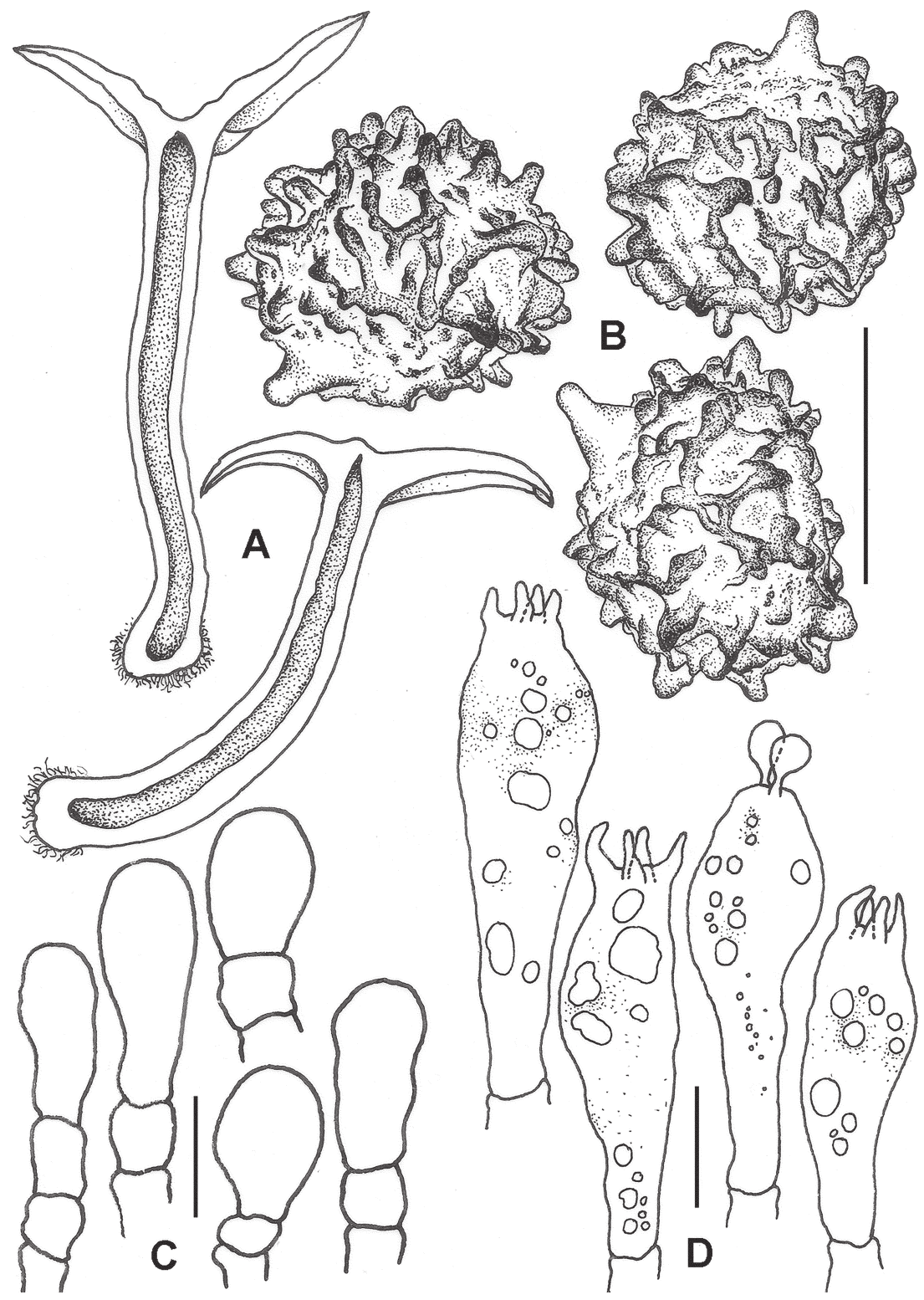

Plate 2: Lactarius indochrysorrheus (Holotype KD 11-002).

A. Fresh basidiomata showing lamellae and lamellulae. B. Basidiospores.

C. Marginal cells. D. Basidia. Scale bars: $B=5 \mu \mathrm{m} ; \mathrm{C}, \mathrm{D}=10 \mu \mathrm{m}$. 
ridges which are aligned or connected and forming a partial to incomplete reticulum; some isolated small warts present; plage sometimes distinct and amyloid. BAsidia $30-44 \times 9-13 \mu \mathrm{m}, 4$-spored, subclavate to ventricose; sterigmata $2.5-4 \times 1.5-2 \mu \mathrm{m}$. Pleuromacrocystidia $32-70 \times 7.5-11 \mu \mathrm{m}$, fairly abundant, emergent $\leq 10-30 \mu \mathrm{m}$, narrowly clavate, cylindric with tapered apex or fusoid, often with mucronate to subcapitate apex, slightly thick-walled (wall $\leq 0.5 \mu \mathrm{m}$ ); content refractive. Pleuropseudocystidia filamentous, 3-5 $\mu \mathrm{m}$ wide. LAMELLAR EDGe fertile with basidia, cystidia and marginal cells. Cheilomacrocystidia 35-55 × 8-9 $\mu \mathrm{m}$, moderately abundant, subclavate to narrowly clavate or ventricose to fusoid sometimes with mucronate apex; content refractive. Cheilopseudocystidia filamentous. Marginal Cells $11-20 \times 7-11 \mu \mathrm{m}$, mostly clavate to subclavate, often multiseptate. Hymenophoral trama with lactifers. Pileipellis an ixocutis, $\leq 170 \mu \mathrm{m}$ thick, with gelatinous layer mostly extended $10-15 \mu \mathrm{m}$ beyond the hyphal layer; hyphae repent to suberect, $\leq 3.5 \mu \mathrm{m}$ wide, branched, septate. STIPITIPELLIS an ixocutis, composed of repent hyphae mostly in parallel pattern; hyphae $\leq 3.5 \mu \mathrm{m}$ wide, branched, septate. STIPE TRAMA mostly with numerous nested sphaerocytes. Clamp CONNECTIONS absent.

Ecology \& Distribution - Gregarious under Abies densa and Picea spinulosa in subalpine coniferous or mixed (coniferous and broadleaf) forest. August. Fairly common.

Additional specimens eXamined: INDIA. Siкkim: North District, Dombang, $27^{\circ} 43^{\prime} 35.2^{\prime \prime} \mathrm{N} 88^{\circ} 45^{\prime} 15.2^{\prime \prime}$ E, alt. 2920 m, 14.VIII.2009, A. Verbeken, K. Das \& K.V. Putte, AV-KD-KVP 032 (BSHC, GENT); North District, Shingba Rhododendron sanctuary, $27^{\circ} 43^{\prime} 42.1^{\prime \prime} \mathrm{N} 88^{\circ} 44^{\prime} 58.8^{\prime \prime} \mathrm{E}$, alt. $2889 \mathrm{~m}$, 24.VIII.2011, K. Das, KD 11-082 (BSHC); $27^{\circ} 44^{\prime} 03.5^{\prime \prime} \mathrm{N} 88^{\circ} 44^{\prime} 23.3^{\prime \prime}$ E, alt. 3208 m, 26.VIII.2012, K. Das, KD 11-107 (BSHC).

Notes - Zonate species with similar cap colours and milk that stains quickly sulphur to greenish yellow are European L. chrysorrheus, North American $L$. vinaceorufescens, and an undescribed American species [labeled $L$. aff. chrysorrheus in the phylogenetic tree and TABLE 1]. ITS sequence comparison suggests the new species described here is close to the three species but not conspecific.

Lactarius chrysorrheus is less sticky, which is reflected in the pileipellis structure, a loosely interwoven cutis without distinct slime layer (HeilmannClausen et al. 1998). Lactarius vinaceorufescens differs by a pileipellis with a relatively thin ixocutis and the lack of ixocutis in the stipitipellis (Hesler \& Smith 1979). Lactarius xanthogalus Verbeken \& E. Horak, described from Papua New Guinea (Verbeken \& Horak 2000), has a zonate orange to paler cap and latex that becomes immediately sulphur yellow but clearly differs by the zebroid ornamented spores. 


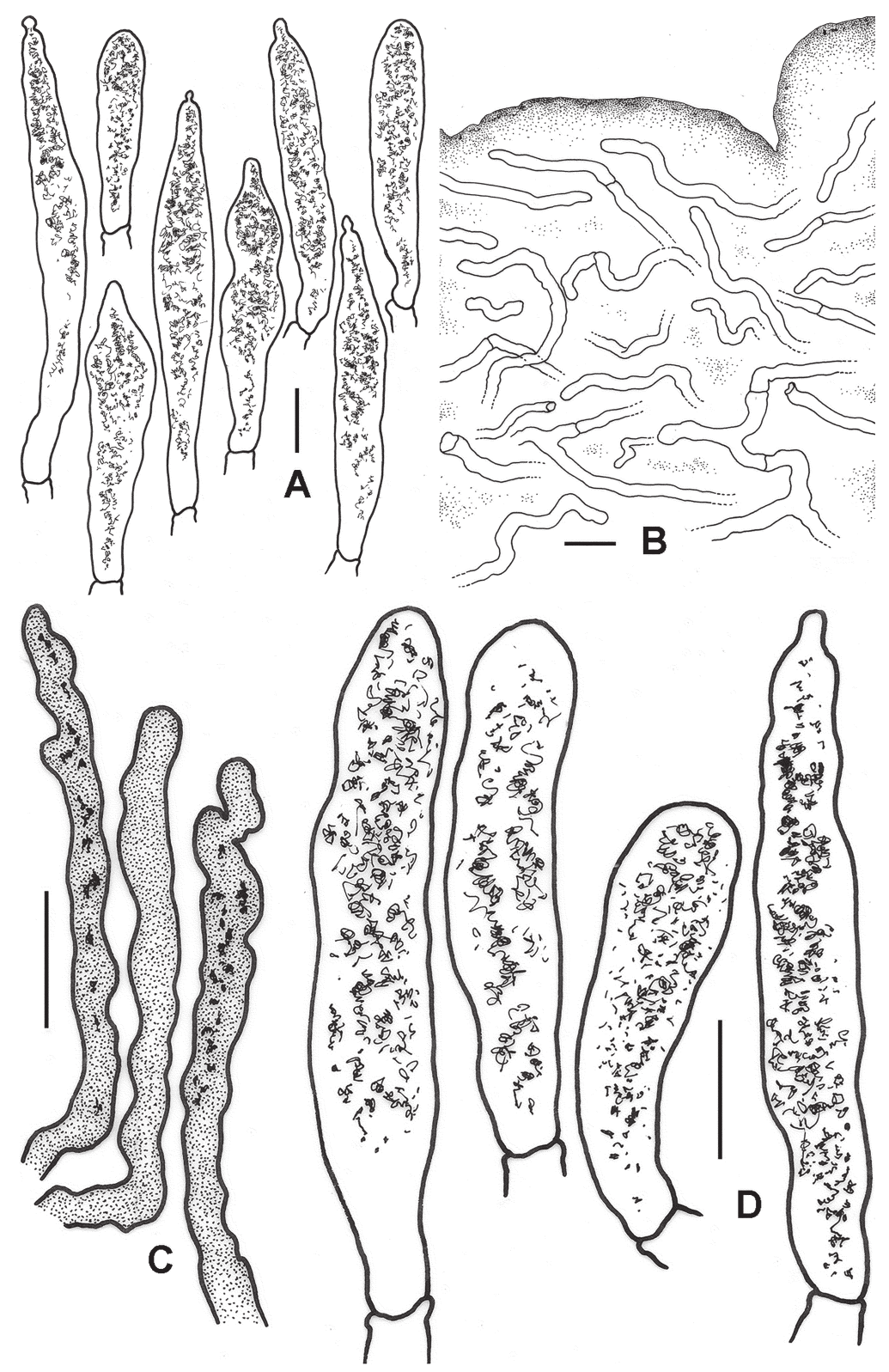

Plate 3. Lactarius indochrysorrheus (Holotype KD 11-002).

A. Pleuromacrocystidia. B. Radial section through pileipellis.

C. Pleuropseudocystidia. D. Cheilomacrocystidia. Scale bars $=10 \mu \mathrm{m}$. 
MycoBank MB 804888

Differs from Lactarius albocarneus by its olivaceous pileus and its watery white latex that turns faintly pinkish on bruised or cut gill tissue.

Type: India. Sikkim: North District, Shingba Rhododendron sanctuary, $27^{\circ} 44^{\prime} 19.5^{\prime \prime} \mathrm{N}$ $88^{\circ} 44^{\prime} 25.9^{\prime \prime} \mathrm{E}$, alt. $3252 \mathrm{~m}$, 26.VIII.2011, K. Das, KD 11-103 (Holotype, BSHC; isotype, GENT).

EтумоLоgy: named after the olive and extremely glutinous pileus of the basidiocarps.

Pileus 40-68(-120) $\mathrm{mm}$ diam., at first convex, gradually becoming planoconvex with slightly depressed centre; surface smooth, viscid to highly glutinous, olive yellow (b: 3D8) to olive brown (b: 4E8, 4F6) or golden brown (b: 5D7) to greenish grey, grey-olive or darker towards centre and paler margin, azonate; margin non-striate, incurved when young, decurved with maturity. LAMELLAE adnexed to broadly adnate, crowded $(17-18 / \mathrm{cm}$ at margin), with lamellulae in 5-6 series, pale cream to cream; edge entire, concolorous. STIPE $40-75 \times 12-17 \mathrm{~mm}$, clavate to subclavate (broader towards base) or ventricose (narrower towards apex and base); surface smooth or sometimes with shallow depressions (but without scrobicules), sticky, pale salmon to pale yellow (b: $3 \mathrm{~A} 3$ to $4 \mathrm{~A} 3$ ), gradually whitish towards base; base strigose, pale cream to white, sometimes with ochraceous spots. ConTExT firm, stuffed to hollow in stipe, cream (a: 4D) to pale cream, unchanging when exposed or with $\mathrm{KOH}$, changing to olivaceous (a: 62) to leaf green (a: 59) with Guaiac and pale green with $\mathrm{FeSO}_{4}$. LATEX whitish, very watery, turning faintly pinkish on bruised or cut lamellae. TASTE mild and agreeable or slightly acrid. OdOuR indistinct. SPORE PRINT pale yellow (c: 30Y, 2M).

BASIDIOSPORES 8.0-9.3-10.1(-11) ×6.7-7.3-7.8(-8.4) $\mu \mathrm{m},[\mathrm{Q}=1.16-1.28-$ $1.33(-1.44)$ ], broadly ellipsoid to ellipsoid; ornamentation amyloid, $\leq 1.2 \mu \mathrm{m}$ high, composed of narrow, low and high ridges aligned and parallel, forming zebroid pattern, some connected with adjacent ones (but never forming a true reticulum), with each high ridge bearing elongated to conical (with rounded apex) warts; plage indistinct. BASIDIA 40-60 × 11.5-13 $\mu \mathrm{m}, 2$-4-spored, ventricose; sterigmata $6-9 \times 2-2.5 \mu \mathrm{m}$. Pleuromacrocystidia 57-88 $\times$ $8-12 \mu \mathrm{m}$, abundant, subcylindric or subclavate to fusiform with rounded, mucronate to moniliform (rarely) apex, emergent $\leq 41 \mu \mathrm{m}$; content dense. Pleuropseudocystidia cylindrical to tortuous, rare, never emergent, 4-5 $\mu \mathrm{m}$ wide; content refringent. LAMELLAR EDGE sterile with marginal cells and some cystidia. Cheilomacrocystidia 32-57 $\times 7-9 \mu$ m, subcylindrical to subfusiform, mostly with rounded apex. MARgINAL CELLS 13-23 × 6.5-9 $\mu \mathrm{m}$, narrowly clavate to clavate or subcapitate, slightly thick-walled, hyaline. Hymenophoral trama with lactifers. Pileipellis an ixotrichoderm, very thick (often variable in thickness), 220-700 $\mu$ m thick, composed of erect, 


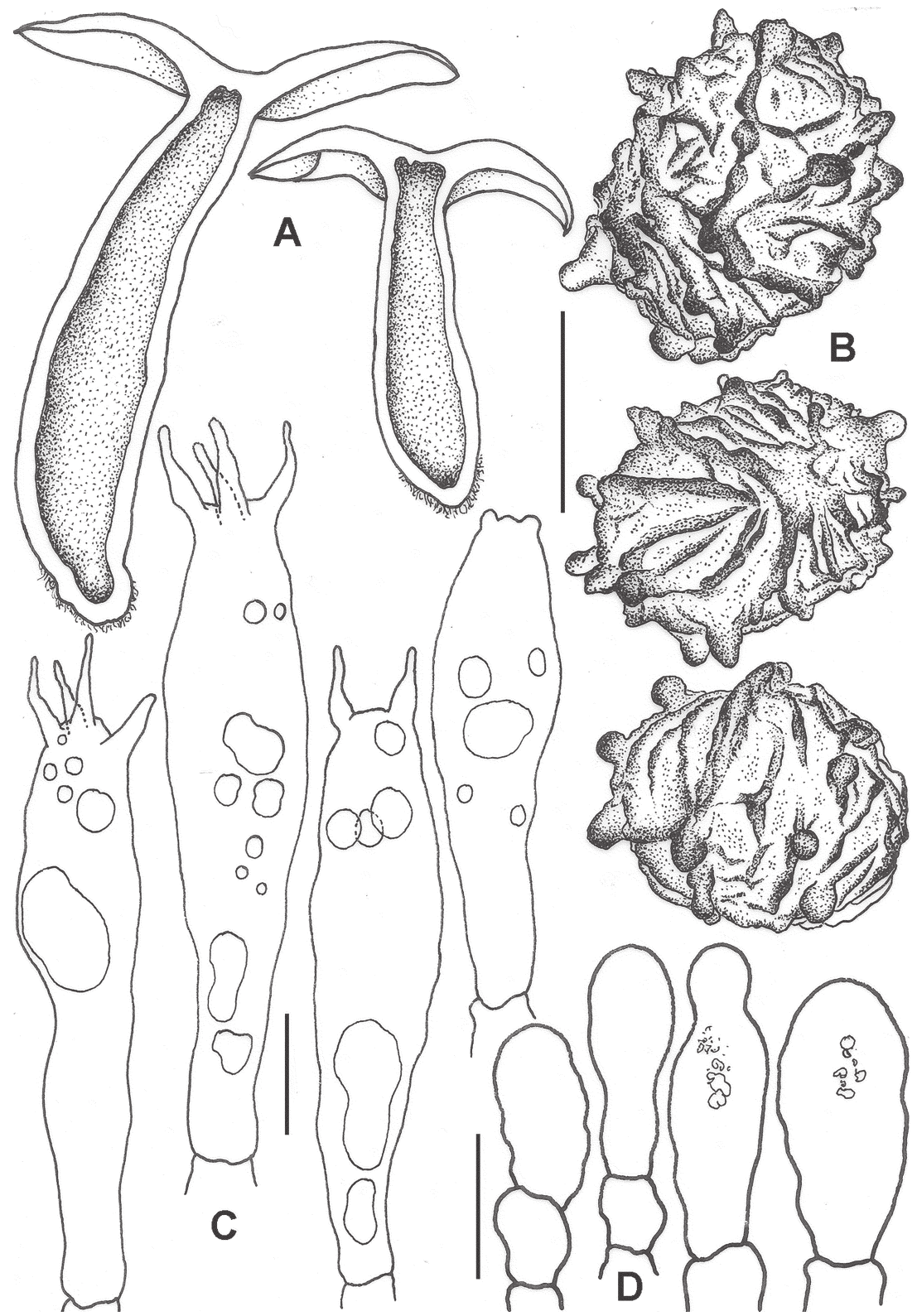

Plate 4. Lactarius olivaceoglutinus (Holotype KD 11-103).

A. Fresh basidiomata showing lamellae and lamellulae. B. Basidiospores.

C. Basidia. D. Marginal cells. Scale bars: $B=5 \mu \mathrm{m} ; \mathrm{C}, \mathrm{D}=10 \mu \mathrm{m}$. 
116 ... Das, Verbeken, \& Nuytinck
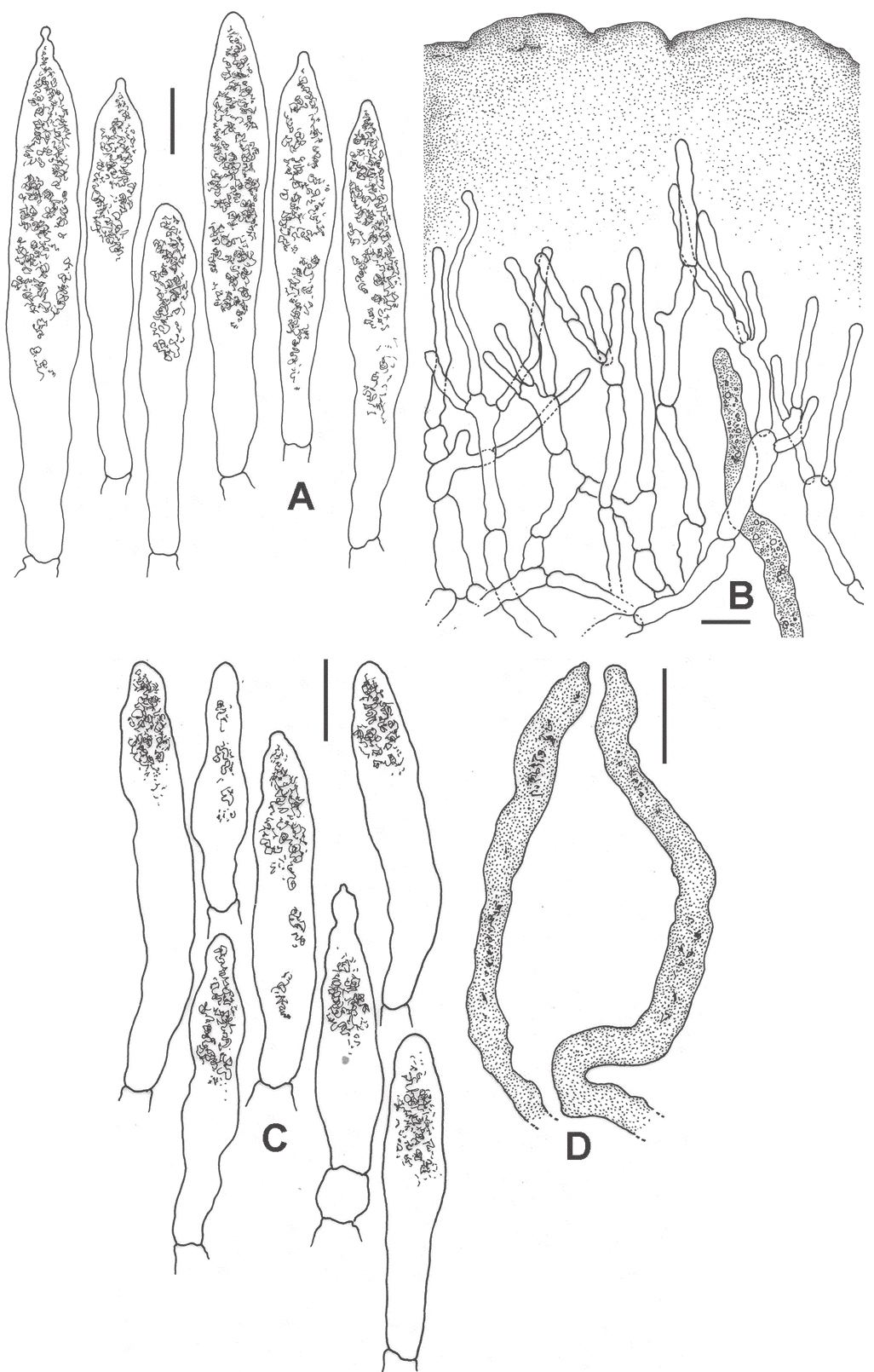

Plate 5. Lactarius olivaceoglutinus (Holotype KD 11-103).

A. Pleuromacrocystidia. B. Radial section through pileipellis.

C. Cheilomacrocystidia. D. Pleuropseudocystidia. Scale bars $=10 \mu \mathrm{m}$. 

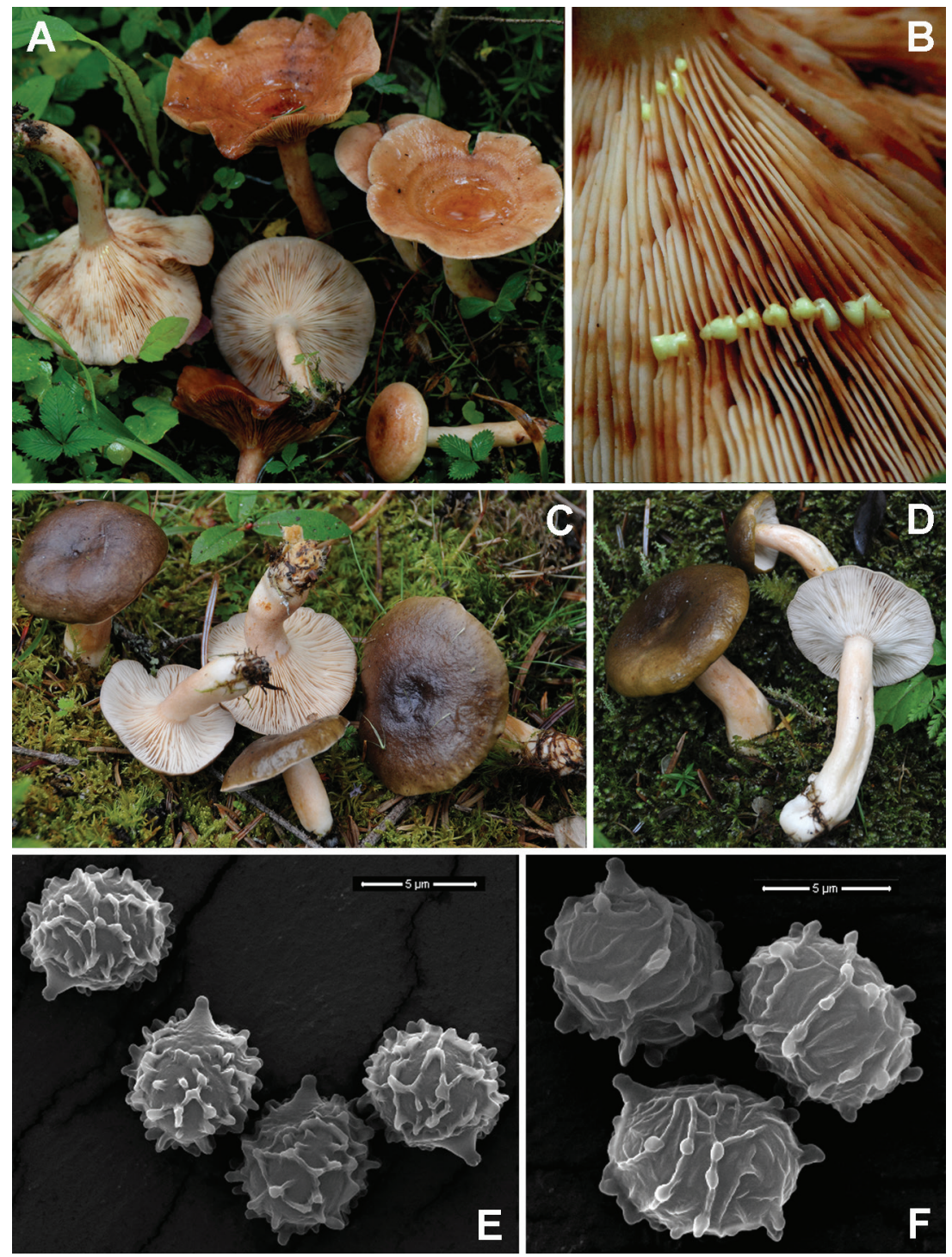

Plate 6. Lactarius indochrysorrheus. A. Fresh basidiomata. B. Latex oozing from cut lamellae. E. Basidiospores (SEM). Lactarius olivaceoglutinus. C, D. Fresh basidiomata. F. Basidiospores (SEM). Scale bars: $\mathrm{E}, \mathrm{F}=5 \mu \mathrm{m}$.

branched multi-septate hyphae ( $\leq 3.5 \mu \mathrm{m}$ wide) and few lactifers embedded in a slime layer of variable thickness underlying somewhat repent hyphae. STIPITIPELLIS an ixotrichoderm, $\leq 120 \mu \mathrm{m}$ thick, composed of erect branched 
septate hyphae ( $\leq 3 \mu \mathrm{m}$ wide) embedded in a slime layer. STIPE Trama with numerous nested sphaerocytes. Clamp connections absent.

Ecology \& Distribution - Gregarious under Abies densa in subalpine coniferous or mixed (coniferous and broadleaf) forest. August-September. Fairly common.

AdDitional sPECIMENS EXAMINED: INDIA. SIKkIM: North District, Shingba Rhododendron sanctuary, $27^{\circ} 45^{\prime} 11.1^{\prime \prime} \mathrm{N} 88^{\circ} 43^{\prime} 47.5^{\prime \prime} \mathrm{E}$, alt. $3580 \mathrm{~m}$, 29.VIII.2011, K.

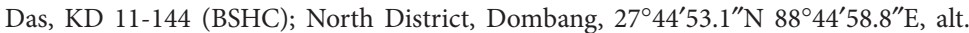

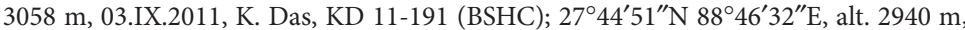
15.VIII.2009, A. Verbeken, K. Das \& K.V. Putte, AV-KD-KVP 09-049 (BSHC, GENT).

Notes - The combination of the viscid to glutinous pileus and stipe and the ixotrichoderm pileipellis clearly places the present species in L. sect. Pallidini. Lactarius olivaceoglutinus can be recognized by its distinctly glutinous grey-olive to greenish grey pileus, pale salmon to pale yellow sticky stipe, whitish watery latex that turns the bruised lamellae faintly pinkish, large spores with mostly zebroid patterns of ridges (that carry warts), and its occurrence under Abies sp. ITS sequences and morphology (mainly the thick pileipellis ixotrichoderm) suggest a close relationship with the European L. albocarneus Britzelm. [= L. glutinopallens F.H. Møller \& J.E. Lange] and North American L. caespitosus Hesler \& A.H. Sm. The pileus of L. albocarneus however, is dominantly cream to at most olivaceous buff and its latex slowly turns to sulfur-yellow (HeilmannClausen et al. 1998, Kränzlin 2005) and its spore ridges never bear elongated to conical warts. Lactarius caespitosus also has a viscid cap with similar grey to olive brown colours, but its spores are slightly larger with a distinctly low and non-zebroid ornamentation (Hesler \& Smith 1979).

In Sikkim L. elaioviscidus K. Das \& Verbeken is another species with a glutinous olivaceous pileus and watery white latex (Das \& Verbeken 2011); however, it is distinguished from L. olivaceoglutinus by the presence of a papilla, its greyish yellow to yellowish white stipe without pinkish tinges, latex changing to yellow-yellowish green after long exposure, and smaller basidiospores without zebroid ornamentation $(7.0-8.1-8.7 \times 6.0-6.7-7.1 \mu \mathrm{m})$.

Lactarius pyriodorus K. Das \& Verbeken, sp. nov.

Plate 7-9, 13A,B,F

MYCOBANK MB 804889

Differs from Lactarius formosus by lacking bundles of glutinous hairs on the pileus.

Type: India. Sikkim: North District, Dombang, $27^{\circ} 44^{\prime} 08.7^{\prime \prime} \mathrm{N}, 88^{\circ} 45^{\prime} 58.3^{\prime \prime}$, alt. $2975 \mathrm{~m}$, 19.VIII.2011, K. Das, KD 11-027 (Holotype, BSHC; isotype, GENT).

ЕтумоLоgy: in reference to the distinct pear-like odor of the fresh basidiocarps.

PILEUs 35-77 mm diam., at first convex with slightly depressed centre, gradually becoming planoconvex with depressed centre and finally broadly to widely infundibuliform, rarely with a small, sometimes blunt central papilla; surface 


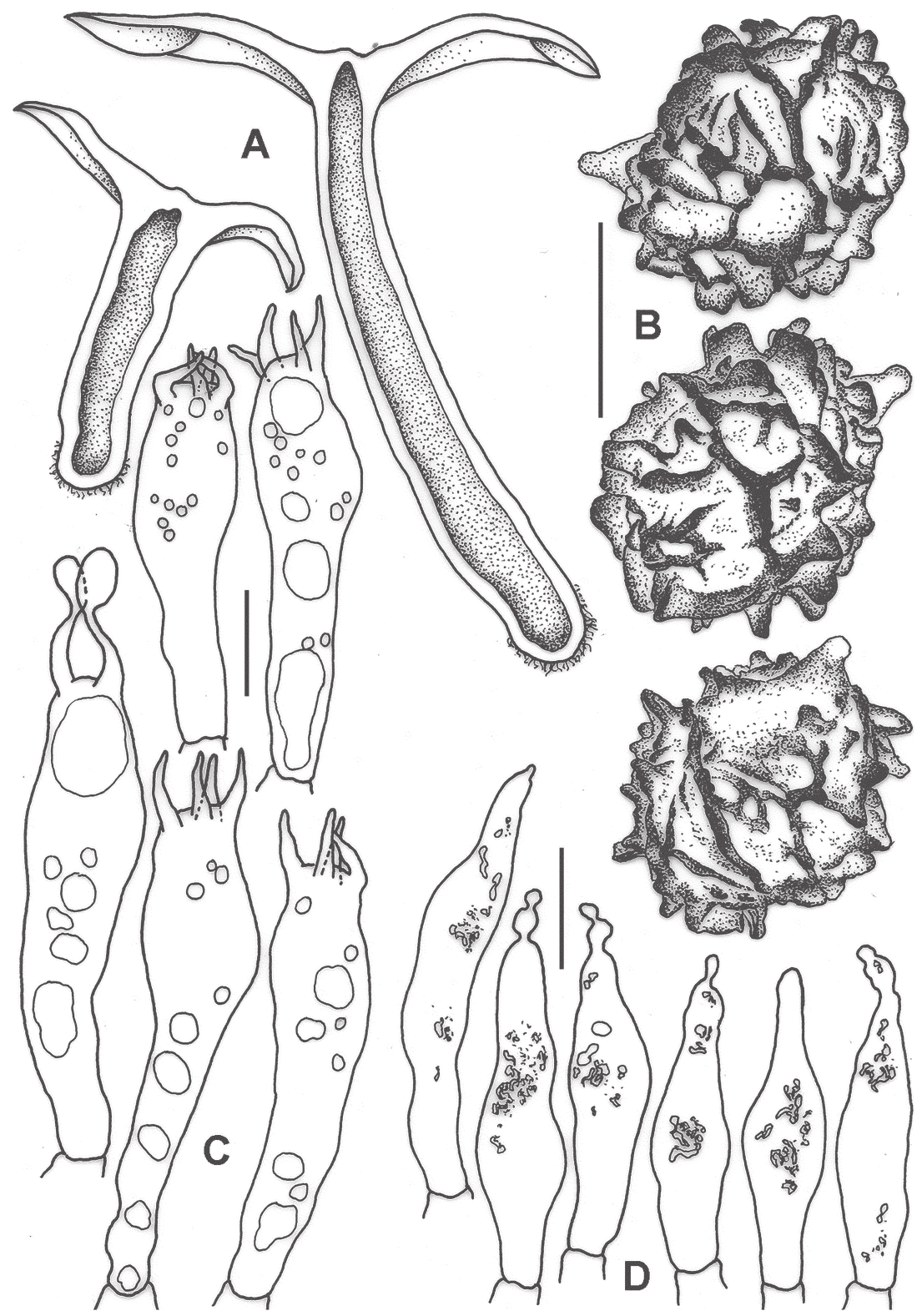

Plate 7. Lactarius pyriodorus (Holotype KD 11-027).

A. Fresh basidiomata showing lamellae and lamellulae. B. Basidiospores.

C. Basidia. D. Cheilomacrocystidia. Scale bars: $B=5 \mu \mathrm{m} ; \mathrm{C}, \mathrm{D}=10 \mu \mathrm{m}$. 
smooth to finely rugulose under the slimy surface, viscid to highly glutinous and slimy, mostly uniformly colored but sometimes with some indistinct fading zones, bay (a: 19) to umber (a: 18), often sienna (a: 11) towards margin with distinct rust (a: 13) to dark brick (a: 20) or brown vinaceous (a: 25), with broader zonations towards centre and narrower zones towards margin; margin non-striate to very finely and shortly striate, incurved when young, decurved with maturity, becoming very irregularly wavy to undulate. LAMELLAE broadly adnate to decurrent, crowded $(15-16 / \mathrm{cm}$ at margin), sometimes forked near the stipe, with lamellulae in 5 series, whitish cream to pale cream, turning livid vinaceous (a: 77) to lilac (a: 79) or darker violet (b: 15D4-5, 15E5) after bruising; edge entire, concolorous. STIPE 35-72 × 10-18 mm, cylindrical or broadest in the middle, narrower towards base, often curved and locally swollen; surface smooth, slightly viscid or sticky, not as viscid as pileus, dingy white to pale cream, buff (a: 52) to vinaceous buff with maturity; base usually paler, strigose. Context firm, rather thick in pileus center and thin in outer half, very soon hollow in stipe, white to pale cream, changing lilac (a: 77; b: 13C3-4) after exposure, leaf green with Guaiac, unchanging with $\mathrm{FeSO}_{4}$ and $\mathrm{KOH}$. LATEX white to pale cream, watery, slowly staining the lamellae or context livid vinaceous (a: 77) to lilac (a: 79), unchanging without the contact of lamellae or context. TASTE mild at first, becoming slightly bitter and astringent. ODOuR fruity, very sweet, like pears (as in Inocybe corydalina Quél.). SPORE PRINT pale cream (c: 10Y).

BASIDIOSPORES 8.0-8.9-10.5 × 6.9-7.5-8.8 $\mu \mathrm{m},(\mathrm{Q}=1.11-1.18-1.32)$, subglobose to broadly ellipsoid, rarely ellipsoid; ornamentation amyloid, $\leq 1.1$ $\mu \mathrm{m}$ high, composed of broad ridges and isolated warts forming a partial to an incomplete reticulum; plage inamyloid or distally amyloid. BAsidia $45-52 \times$ 10.5-12 $\mu \mathrm{m}$, 4-spored, rarely 2 -spored, clavate to ventricose; sterigmata 6-7 $\times 2-2.5 \mu \mathrm{m}$. Pleuromacrocystidia 55-80 $\times 7.5-11 \mu \mathrm{m}$, abundant, fusiform with mucronate to moniliform apex, emergent $\leq 33 \mu \mathrm{m}$; content slightly dense. Pleuropseudocystidia cylindric to slightly tortuous, never emergent, 3.5-4 $\mu \mathrm{m}$ wide; content refringent. Lamellar edge sterile. Cheilomacrocystidia $28-43 \times 6.5-9 \mu \mathrm{m}$, fusiform to lageniform, mostly with moniliform apex. MARGINAL CELls 15-35 × 7-10 $\mu \mathrm{m}$, cylindric to clavate, slightly thick-walled, hyaline. SubHymenium $\leq 20 \mu \mathrm{m}$ thick. Hymenophoral trama with abundant lactifers. Pileipellis an ixocutis to ixotrichoderm, $\leq 320 \mu \mathrm{m}$ thick, composed of few repent hyaline hyphae and abundant erect hyphae $(2-4 \mu \mathrm{m}$ broad). Clamp ConneCtions absent.

Ecology \& Distribution - Gregarious to caespitose under Abies densa and Tsuga dumosa in subalpine mixed (coniferous and broadleaf) forest. August. Fairly common. 


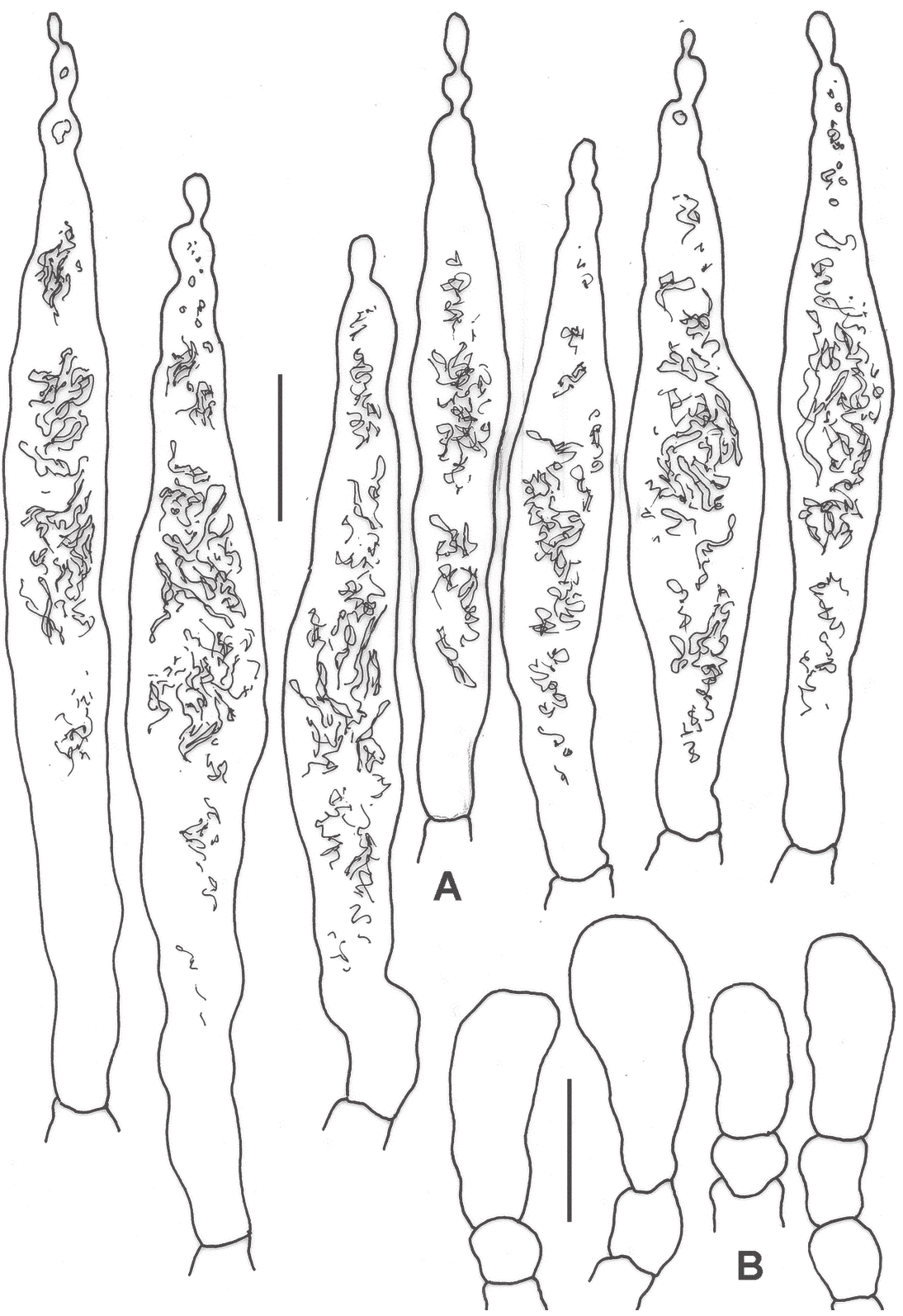

Plate 8. Lactarius pyriodorus (Holotype KD 11-027).

A. Pleuromacrocystidia. B. Marginal cells. Scale bars $=10 \mu \mathrm{m}$. 


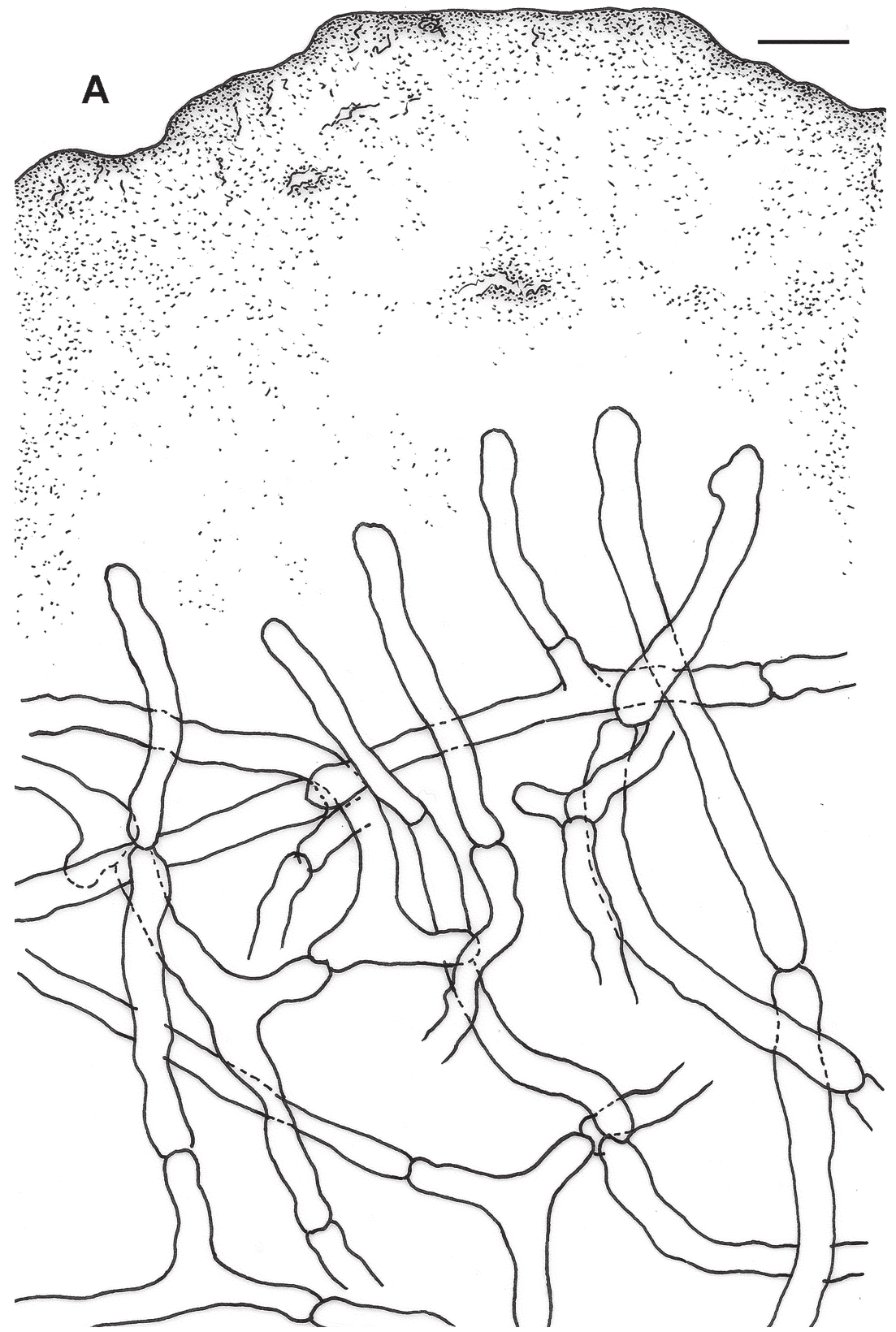

Plate 9. Lactarius pyriodorus (Holotype KD 11-027):.

A. Radial section through pileipellis. Scale bar $=10 \mu \mathrm{m}$. 
Additional specimens examined: INDIA. Sikкim: North District, Dombang, $27^{\circ} 44^{\prime} 08.7^{\prime \prime} \mathrm{N} 88^{\circ} 45^{\prime} 58.3^{\prime \prime}$ E, alt. 2975 m, 14.VIII.2009, A. Verbeken, K. Das \& K.V. Putte, AV-KD-KVP 050 \& 051 (BSHC, GENT); alt. 2945 m, 23.VIII.2011, K. Das, KD 11-068 (BSHC); North District, Zema, 27 $47^{\prime} 20.0^{\prime \prime} \mathrm{N} 88^{\circ} 32^{\prime} 56.1^{\prime \prime} \mathrm{E}$, alt. 3079 m, 31.VIII.2012, K. Das, KD 12-223, KD 12-226 (BSHC).

Notes - The viscid to glutinous subzonate pileus, ixocutis to ixotrichoderm nature of the pileipellis, and latex that stains the context and lamellae distinctly lilac to violet place this species in $L$. sect. Uvidi. Only one representative of L. subg. Piperites with lilac milk has been described from Asia (northern Thailand) - L. formosus H.T. Le \& Verbeken (Le et al. 2007). Lactarius formosus clearly differs from $L$. pyriodorus because its pileus is completely covered with bundles of glutinous hairs.

In the ITS-generated phylogenetic tree, the resolution in the group of lilac staining species is very low, and the Indian species is not distinctly separated from a cluster with the European species Lactarius luridus (Pers.) Gray and L. brunneoviolaceus M.P. Christ. We have previously observed that in this group the morphological variation appears much higher than the ITS molecular variation. Since we observe clear morphological differences between L. pyriodorus and the European taxa (also not supported in this tree, although generally accepted as separate species), we choose to present these Indian specimens as a new species. Its darker colours and subzonate aspect are shared with $L$. luridus, which typically associates with broadleaf trees and can be separated by its pileus that is spotted but never with thick gluten (as in L. pyriodorus). Also, in L. luridus, the stipe base is never strigose and the distinctive sweetish pear-like odour is absent (Heilmann-Clausen et al. 1998). Lactarius brunneoviolaceus and L. pseudouvidus Kühner are two arctic-alpine species associated with Salix that differ greatly from our Indian species in their very small habit. Lactarius brunneoviolaceus is further distinguished by its cedar-oil odour and rather large spores (8.8-11.9 × 6.7-8.6 $\mu \mathrm{m})$ (HeilmannClausen et al. 1998, Basso 1999). Lactarius pseudouvidus differs microscopically by its distinctly lower $(\leq 0.3 \mu \mathrm{m})$ spore ornamentation and differently shaped hymenial cystidia (cylindric to subfusiform with rounded apex) (HeilmannClausen et al. 1998). Lactarius pyriodorus is superficially similar to the European L. uvidus (Fr.) Fr., which can also occur under coniferous trees, but it never has such dark colours (Heilmann-Clausen et al. 1998), and its spores have rounded warts and ridges forming a more incomplete reticulum.

This is for the first time that distinct sweetish odour reminiscent of pears (also known from the European Inocybe corydalina) has been encountered in Lactarius. 
Lactarius yumthangensis $\mathrm{K}$. Das \& Verbeken, sp. nov.

MycoBank MB 804890

Differs from Lactarius trivialis by its lighter spore print, smaller spores, and pileipellis ixocutis.

Type: India. Sikkim: North District, Yumthang valley of Shingba Rhododendron sanctuary, $27^{\circ} 46^{\prime} 51.9^{\prime \prime} \mathrm{N} 88^{\circ} 42^{\prime} 37.6^{\prime \prime}$ E, alt. 3586 m, 30.VIII.2011, K. Das, KD 11-147 (Holotype, BSHC, isotype, GENT).

ЕтумодоgY: after the name of the locality from where the type specimen was collected

Pileus 37-98 mm diam., at first convex with inrolled margin, becoming planoconvex to applanate with depressed indented centre or funnel shaped at maturity, surface smooth, viscid when dry, slimy when moist, vinaceous grey (a: 80) or slightly paler (purplish grey), mostly with distinct darker spots forming zonations; margin non-striate, paler, decurved with maturity. LAMELLAE broadly adnate to decurrent, close to medium crowded $(9-11 / \mathrm{cm}$ at margin), some forked, with lamellulae in 5 series, cream-yellow to yellow (a: $6 \mathrm{~F}$ ) or ochraceous, sometimes with rusty spots after maturity, unchanging when bruised; edge entire, concolorous. STIPE 21-50 ×9-22 mm, cylindrical to ventricose, often constricted below the juncture of the lamellae, surface slightly longitudinally venose, whitish on constriction, then vinaceous to vinaceous grey (a: 80), cream yellow towards base, with ochraceous areas/spots towards base after maturity. ConteXT yellowish white to cream, hollow, multi-chambered in stipe, becoming greenish with $\mathrm{FeSO}_{4}$ and orange-yellow with $\mathrm{KOH}$. LATEX chalky white, changing to orange-yellow with $\mathrm{KOH}$, turning pale cream (a: 3C) after some time, slowly (on drying) greenish yellow (a: 57) after 2 hours (on cut lamellae). TASTE acrid. Odour fruity. Spore PRINT pale yellow (c: 30Y, 2M).

BASIDIOSPORES 6.4-7.1-8.0 $\times$ 5.3-6.0-6.9 $\mu \mathrm{m},(\mathrm{Q}=1.06-1.18-1.32)$, subglobose to ellipsoid; ornamentation amyloid, $\leq 1 \mu \mathrm{m}$ high, composed of rather regular, narrow and acute ridges mostly arranged in parallel groups forming zebroid pattern, short ridges and isolated irregular warts present between ridges, but, never forming reticulum; plage amyloid distally but often not distinguishable. BAsIDIA 38-58 $\times 9-11 \mu \mathrm{m}, 2-4$-spored, clavate to ventricose; sterigmata long, 5-9 $\times 2-2.5 \mu \mathrm{m}$. Pleuromacrocystidia 44-90 $\times 7.5-10 \mu \mathrm{m}$, abundant, clavate to fusiform (sometimes with mucronate apex), emergent $\leq 36 \mu \mathrm{m}$; content slightly dense but never needle-like, slightly thickwalled (wall up to $0.6 \mu \mathrm{m}$ ). Pleuropseudocystidia irregularly tortuous with rounded apex, 2.5-4 $\mu$ m wide; contents dense. LAMELLAR EDGE sterile. Cheilomacrocystidia $27-55 \times 8-9 \mu \mathrm{m}$, subclavate or narrowly clavate to fusoid, emergent $\leq 25 \mu \mathrm{m}$, slightly thick walled (wall $\leq 0.7 \mu \mathrm{m}$ ). MARGINAL CELLS forming chains of elements, terminal cells 11-18 $\times 5-8 \mu \mathrm{m}$, subcylindric to subclavate or clavate, hyaline. Subhymenium $\leq 28 \mu \mathrm{m}$ thick, cellular. 


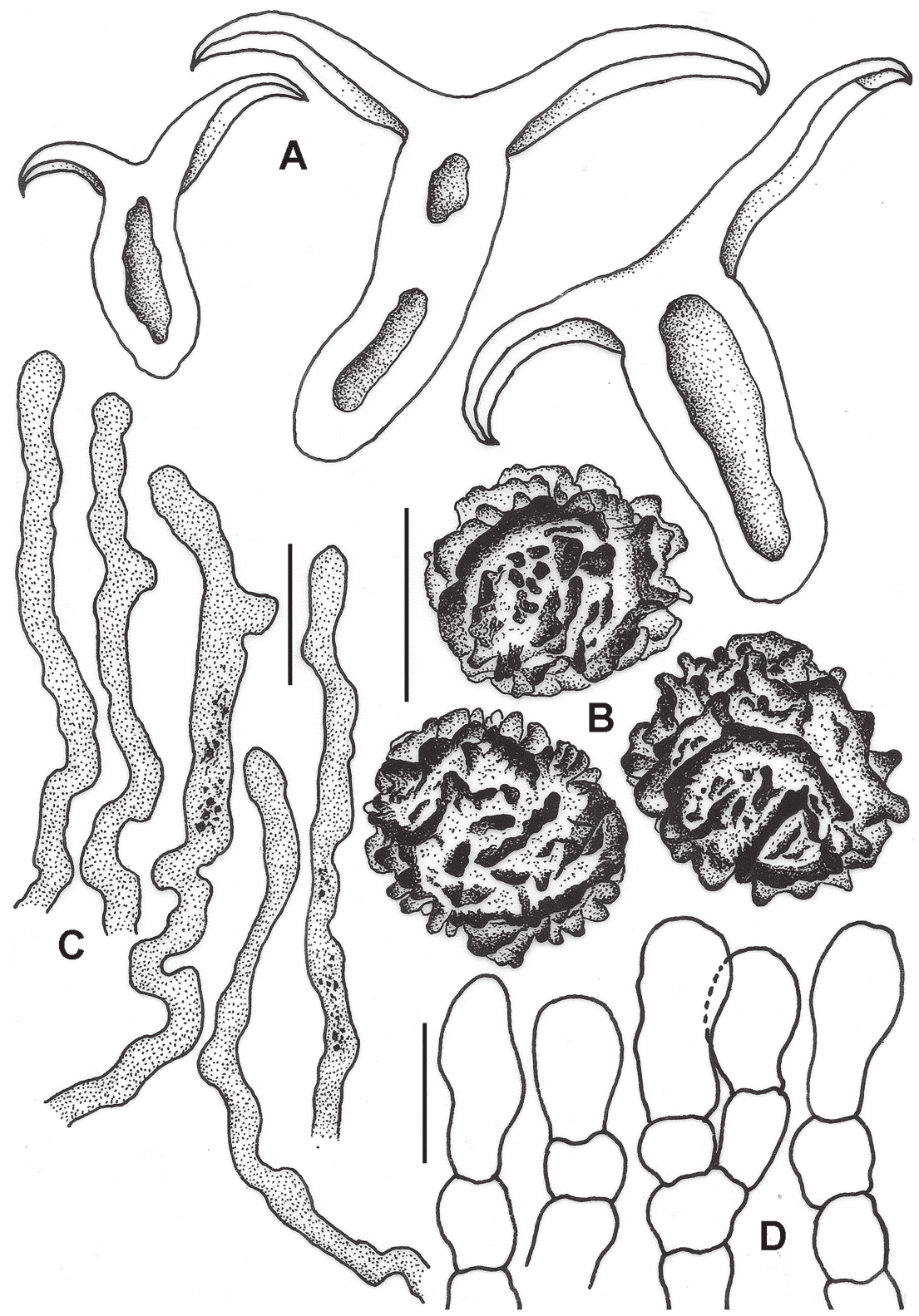

Plate 10:. Lactarius yumthangensis (Holotype KD 11-147).

A. Fresh basidiomata showing lamellae and lamellulae. B. Basidiospores.

C. Pleuropseudocystidia. D. Marginal cells. Scale bars: B $=5 \mu \mathrm{m} ; \mathrm{C}, \mathrm{D}=10 \mu \mathrm{m}$. 


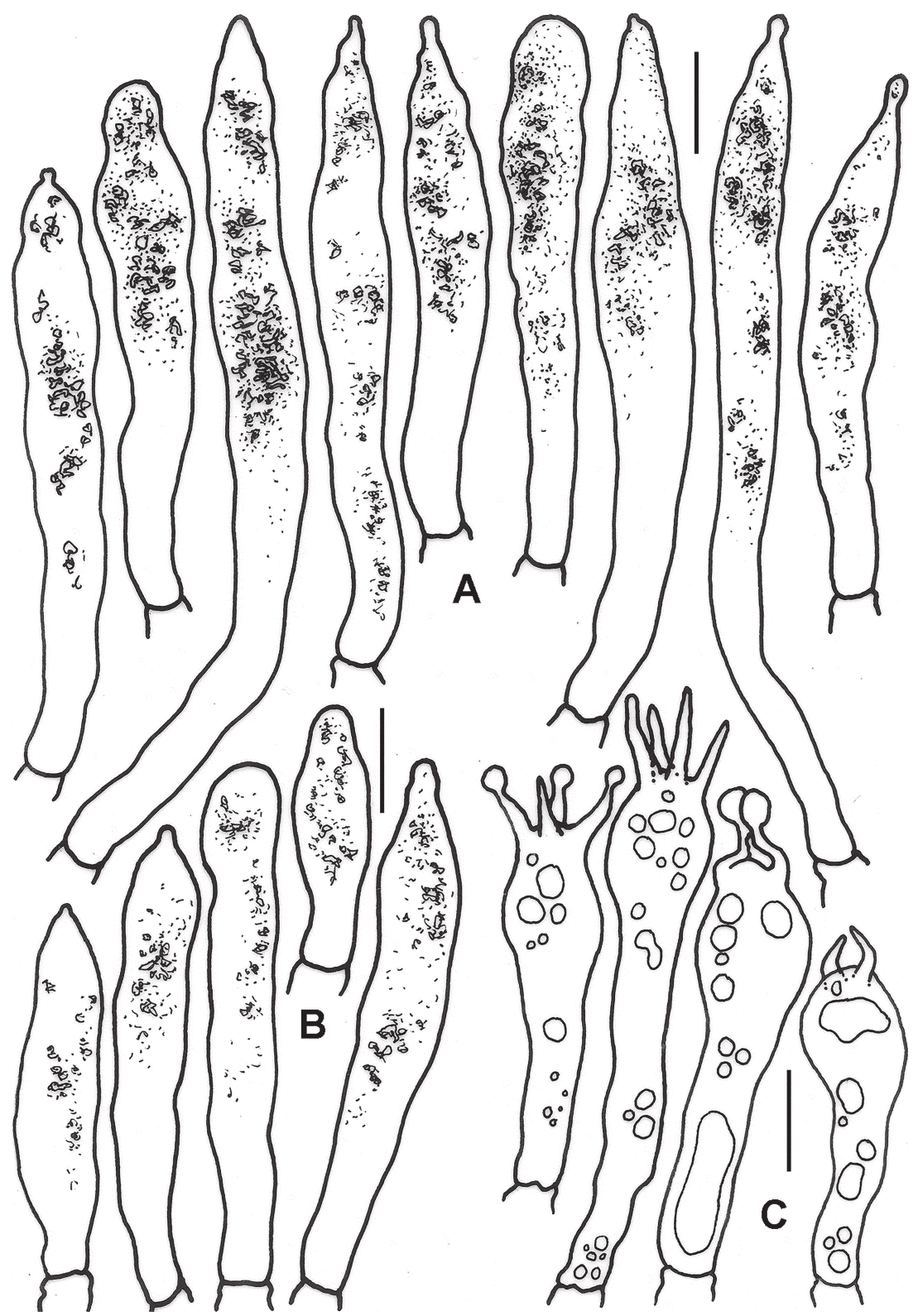

PLATE 11. Lactarius yumthangensis (Holotype KD 11-147).

A. Pleuromacrocystidia. B. Cheilomacrocystidia. C. Basidia. Scale bars $=10 \mu \mathrm{m}$. 


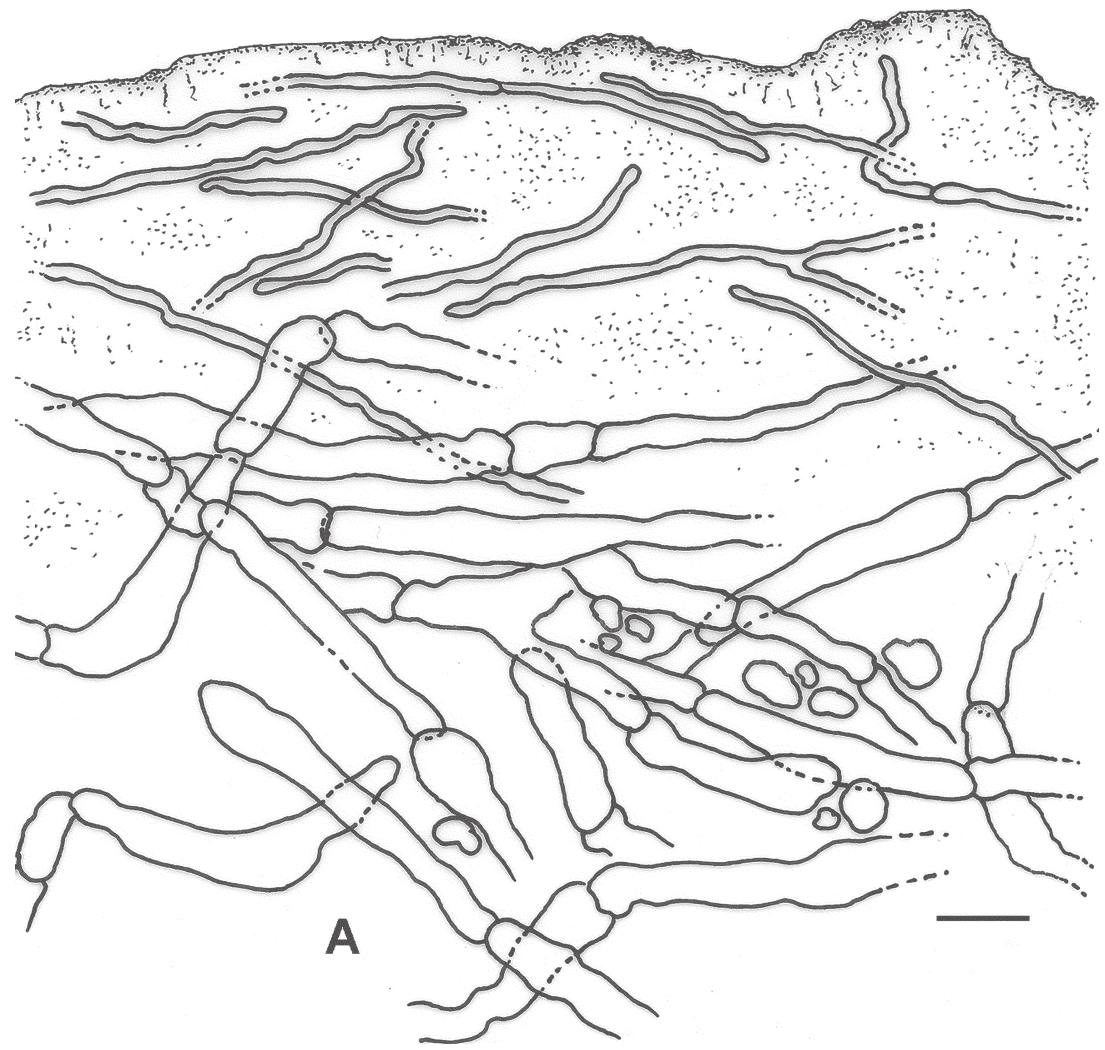

Plate 12. Lactarius yumthangensis (Holotype KD 11-147).

A. Radial section through pileipellis. Scale bar $=10 \mu \mathrm{m}$.

PiLeipellis an ixocutis, composed of narrow repent hyaline hyphae and broad $(\leq 7 \mu \mathrm{m})$ septate hyphae embedded in a layer of slime. Clamp ConNeCtions absent.

Ecology \& Distribution - Gregarious to caespitose under Betula utilis in subalpine mixed (coniferous and broadleaf) forest. August-September. Uncommon.

Additional specimens EXAMined: INDIA. Sikкim: North District, Yumthang valley of Shingba Rhododendron sanctuary, $27^{\circ} 46^{\prime} 51.9^{\prime \prime} \mathrm{N} 88^{\circ} 42^{\prime} 37.6^{\prime \prime} \mathrm{E}$, alt. $3586 \mathrm{~m}$, 29.VIII.2011, K. Das, KD 11-150 (BSHC); $27^{\circ} 45^{\prime} 11.1^{\prime \prime} \mathrm{N} 88^{\circ} 43^{\prime} 47.5^{\prime \prime} \mathrm{E}$, alt. $3580 \mathrm{~m}$, 01.IX.2011, K. Das, KD 11-172 (BSHC).

Notes - The viscid to slimy zonate pileus and the ixocutis to ixotrichoderm nature of the pileipellis undoubtedly place the present species in $L$. subg. 

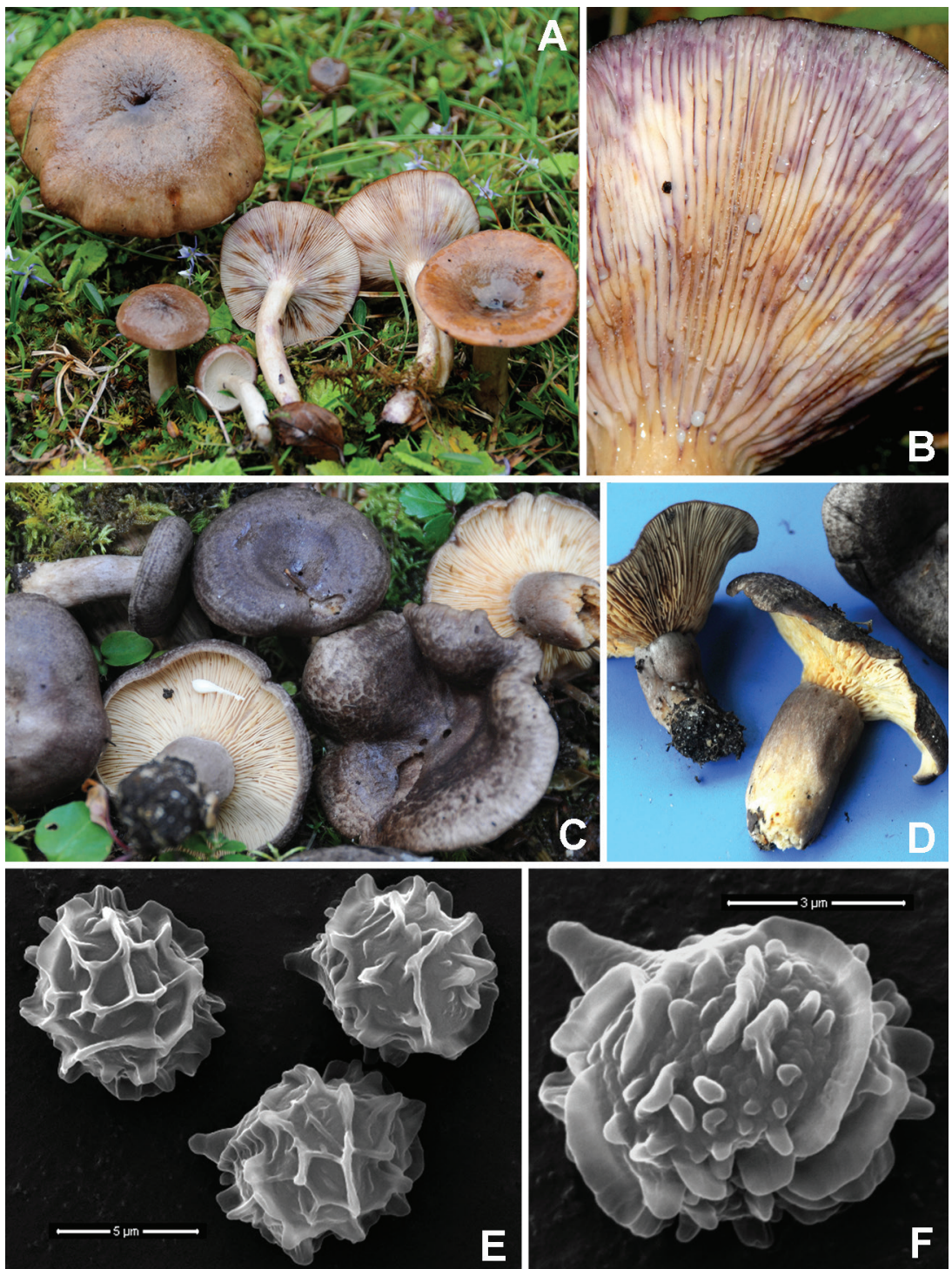

Plate 13. Lactarius pyriodorus. A. Fresh basidiomata. B. Latex oozes out from cut lamellae. E. Basidiospores (SEM). Lactarius yumthangensis. C. Fresh basidiomata. D. Basidiomata showing constricted stipe-apex. F. Basidiospores (SEM). Scale bars: $\mathrm{E}=5 \mu \mathrm{m} ; \mathrm{F}=3 \mu \mathrm{m}$.

Piperites. Lactarius yumthangensis can be recognized by its vinaceous grey to purplish grey pileus, venose stipe with a constricted apex, chalky white latex 
that changes to orange-yellow with $\mathrm{KOH}$ and becomes greenish yellow after long exposure, and growth under Betula sp.

Morphologically, L. flexuosus (Pers.) Gray and L. trivialis (Fr.) Fr. (both reported from Europe) appear quite similar. However, both can be distinguished from L. yumthangensis by the slightly darker spore print (c: 40Y, 5M). Moreover, the white latex of $L$. flexuosus is unchanging (never becoming greenish yellow after exposure), the stipe is not constricted at the apex (Kränzlin 2005), and some cheilomacrocystidia have a moniliform apex (Heilmann-Clausen et al. 1998). In L. trivialis, spores are distinctly larger $(7.3-10 \times 5.9-7.8 \mu \mathrm{m})$ and the pileipellis is an ixocutis to ixotrichoderm (Heilmann-Clausen et al. 1998).

\section{Acknowledgments}

The authors are thankful to the Director, Botanical Survey of India, Kolkata (India) and Department of Forest, Environment and Wild Life Management, Government of Sikkim, for providing all kinds of facilities during this study. They are grateful to Prof. N.S. Atri (India) and Dr. Xiang-Hua Wang (China) for reviewing the manuscript and giving valuable suggestions. Thanks are also due to Ursula Eberhardt, who kindly provided the sequences for the specimens. Assistance (during macrofungal surveys to Dombang, Shingba Rhododendron sanctuary, and Zema) rendered by S.K. Rai, S. Pradhan, R. Giri, R.K. Ram and P. Tamang (BSI, SHRC, Gangtok) is duly acknowledged.

\section{Literature cited}

Basso MT. 1999. Lactarius Pers. Fungi Europaei, vol. 7. Mycoflora, Alassio.

Berkeley MJ. 1852. Decades of Fungi: Decades XXXIX., XL. Sikkim and Khassya Fungi. Hooker's J. Bot. 4: 130-142.

Buyck B, Hofstetter V, Eberhardt U, Verbeken A, Kauff F. 2008. Walking the thin line between Russula and Lactarius: the dilemma of Russula sect. Ochricompactae. Fungal Diversity 28: 15-40.

Buyck B, Hofstetter V, Verbeken A, Walleyn R. 2010. Proposal to conserve Lactarius nom. cons. (Basidiomycota) with a conserved type. Taxon 59(1): 295-296.

Castresana J. 2000. Selection of conserved blocks from multiple alignments for their use in phylogenetic analysis. Mol. Biol. Evol. 17(4): 540-552. http://dx.doi.org/10.1093/oxfordjournals.molbev.a026334

Das K. 2009. Mushrooms of Sikkim 1: Barsey Rhododendron Sanctuary. Sikkim State Biodiversity Board, Gangtok and Botanical Survey of India, Kolkata.

Das K, Verbeken A. 2011. Three new species of Lactarius from Sikkim, India. Cryptogamie Mycologie 32(4): 365-381. http://dx.doi.org/10.7872/crym.v32.iss4.2011.365

Das K, Verbeken A. 2012. New Species of Lactarius Subg. Plinthogalus and new records of Lactifluus subg. Gerardii (Russulaceae) from Sikkim, India. Taiwania 57(1): 37-48.

Das K, Van de Putte K, Buyck B. 2010. New or interesting Russula from Sikkim Himalaya (India). Cryptogamie Mycologie 31(4): 373-387.

Das K, Atri NS, Buyck B. 2013. Three new species of Russula (Russulales) from India. Mycosphere 4(4): 707-717. http://dx.doi.org/10.5943/mycosphere/4/4/9

Gardes M, Bruns TD. 1993. ITS primers with enhanced specificity for Basidiomycetes application to the identification of mycorrhizae and rusts. Molecular Ecology 2: 113-118. http://dx.doi.org/10.1111/j.1365-294X.1993.tb00005.x 
130 ... Das, Verbeken, \& Nuytinck

Hall TA. 1999. BioEdit: a user-friendly biological sequence alignment editor and analysis program for Windows 95/98/NT. Nucleic Acids Symposium Series 41: 95-98.

Heilmann-Clausen J, Verbeken A, Vesterholt J. 1998. The genus Lactarius. Fungi of Northern Europe, vol. 2. The Danish Mycological Society.

Henderson DM, Orton PD, Watling R. 1969. British fungus flora: agarics and boleti: colour identification chart. Royal Botanic Garden Edinburgh, UK.

Hesler LR, Smith AH. 1979. North American species of Lactarius. USA, Ann Arbor, University of Michigan Press.

Holmgren PK, Holmgren NH, Barnett LC. 1990. Index Herbariorum. Part 1: Herbaria of the world, $86^{\text {th }}$ ed. Bronx: New York Botanical Garden, USA.

Katoh K, Standley DM. 2013. MAFFT multiple sequence alignment software version 7: improvements in performance and usability. Molecular Biology and Evolution 30: 772-780. http://dx.doi.org/10.1093/molbev/mst010

Kornerup A, Wanscher JH. 1981. Methuen handbook of colour. UK, London, EyreMethuen Ltd. Reprint.

Kränzlin, F. 2005. Fungi of Switzerland. Volume 6, Russulaceae. Verlag Mykologia Luzern, Switzerland.

Le HT, Nuytinck J, Verbeken A, Desjardin DE, Lumyong S. 2007. Lactarius in Northern Thailand: 1. Lactarius subg. Piperites. Fungal Diversity 24: 173-224.

Nuytinck J, Verbeken A. 2003. Lactarius sanguifluus versus Lactarius vinosus molecular and morphological analyses. Mycological Progress 2: 227-234. http://dx.doi.org/10.1007/s11557-006-0060-5

Stamatakis A. 2006. RAxML-VI-HPC: maximum likelihood-based phylogenetic analyses with thousands of taxa and mixed models. Bioinformatics 22: 2688-2690. http://dx.doi.org/10.1093/bioinformatics/btl446

Van de Putte K, Nuytinck J, Stubbe D, Le HT, Verbeken A. 2010. Lactarius volemus sensu lato (Russulales) from northern Thailand: morphological and phylogenetic species concepts explored. Fungal Diversity 45: 99-130. http://dx.doi.org/10.1007/s13225-010-0070-0

Van de Putte K, Nuytinck J, Das K, Verbeken A. 2012. Exposing hidden diversity by concordant genealogies and morphology-a study of the Lactifluus volemus (Russulales) species complex in Sikkim Himalaya (India). Fungal Diversity 55: 171-194. http://dx.doi.org/10.1007/s13225-012-0162-0

Verbeken A, Horak E. 2000. Lactarius (Basidiomycota) in Papua New Guinea. 2. Species in tropicalmontane rainforest. Austr. Syst. Bot. 13: 649-707. http://dx.doi.org/10.1071/SB99023

Verbeken A, Nuytinck J. 2013. Not every milkcap is a Lactarius. Scripta Botanica Belgica 51: $162-168$.

White TJ, Bruns T, Lee SS, Taylor J. 1990. Amplification and direct sequencing of fungal ribosomal RNA genes for phylogenetics. 315-322, in: MA Innis et al. (eds). PCR Protocols: a guide to methods and applications. Academic Press, New York. 